\title{
Innovative Activity in \\ Canadian Food Processing Establishments: The Importance of Engineering Practices
}

\author{
by \\ John R. Baldwin * \\ and \\ David Sabourin ** \\ No. 101 \\ 11F0019MPE No. 101 \\ ISSN: 1200-5223 \\ ISBN: 0-660-16921-5 \\ Micro-Economic Analysis Division \\ 24-B R.H. Coats Building \\ Ottawa, K1A 0T6 \\ Statistics Canada \\ (613) 951-8588* \\ Email: baldjoh@statcan.ca \\ (613) 951-3735** \\ Email: sabodav@statcan.ca \\ Facsimile Number: (613) 951-5403
}

\section{November 1999}

This paper is to be published in the International Journal of Technology Management. Interested readers are referred to the soon-to-be-released Statistics Canada publication "Advanced Technology in the Canadian Food Processing Industry", catalogue number 88-518-XPE, for detailed results of the survey upon which this paper is based.

This paper represents the views of the authors and does not necessarily reflect the opinions of Statistics Canada. 



\section{Table of Contents}

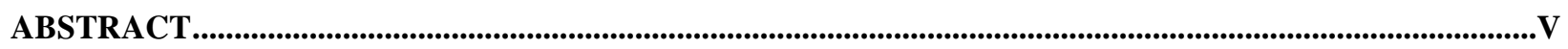

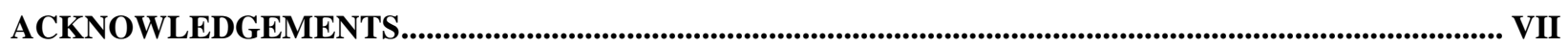

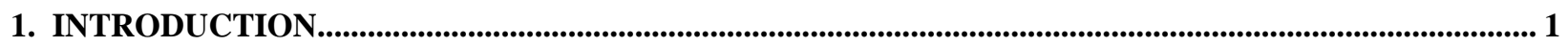

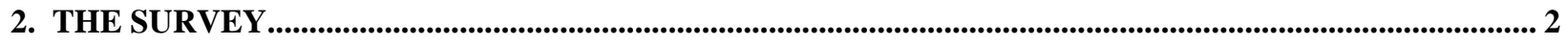

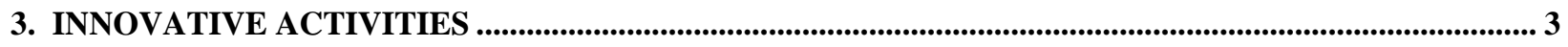

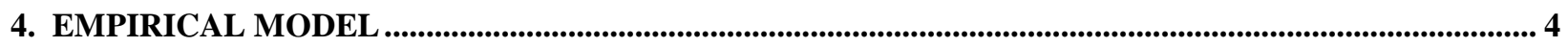

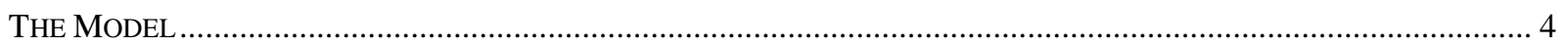

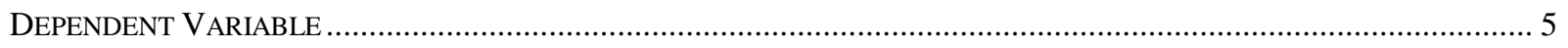

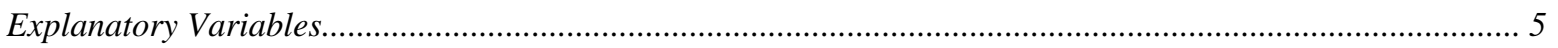

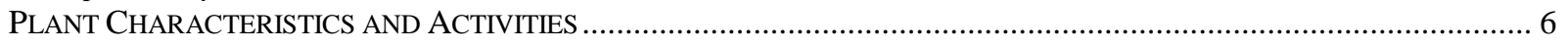

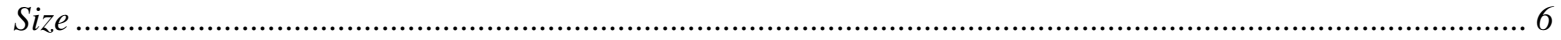

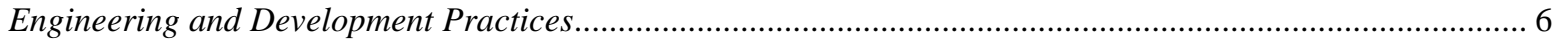

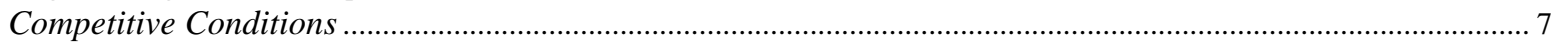

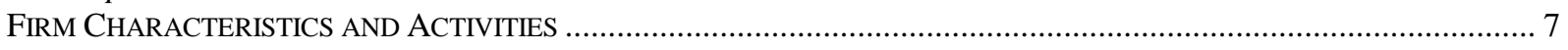

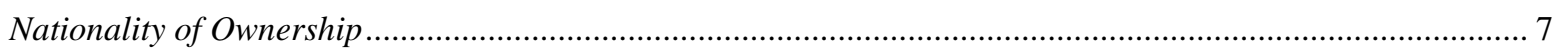

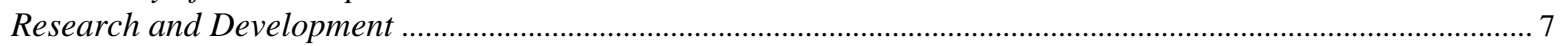

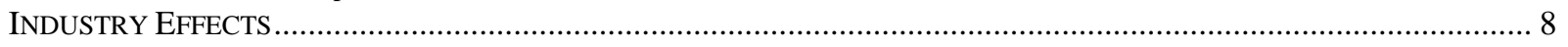

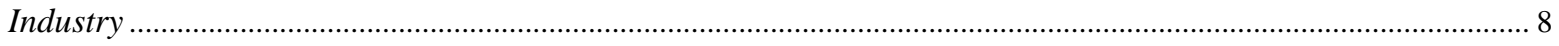

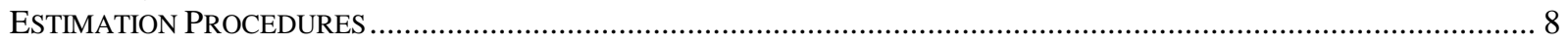

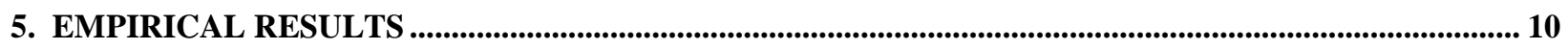

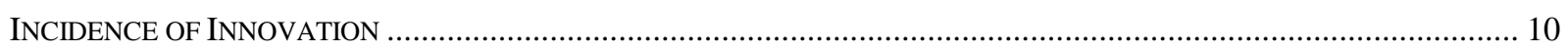

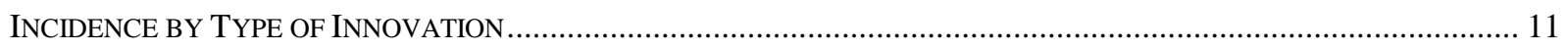

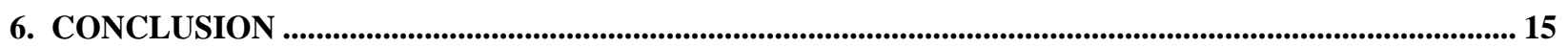

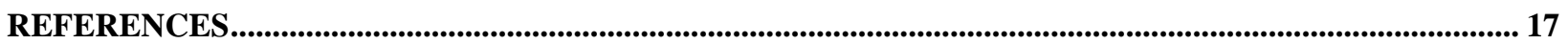

Analytical Studies Branch - Research Paper Series $\quad$ - iii - $\quad$ Statistics Canada No. 11F0019MPE No. 101 



\section{Abstract}

This paper examines the factors contributing to innovative activity in the Canadian food processing sector. The study first focuses on the importance of research and development activity and advanced business practices used by production and engineering departments. Second, it examines the extent to which larger firm size and less competition serve to stimulate competition - the so-called Schumpeterian hypothesis. Third, the effect of the nationality of a firm on innovation is investigated. Finally, industry effects are examined.

The paper finds that business practices are significantly related to the probability that a firm is innovative. This is also the case for R\&D. Size effects are significant, particularly for process innovations. Elsewhere, their effect is greatly diminished once business practices are included. Foreign ownership is significant only for process innovations and not for product innovations. Competition matters, more so for product than for process innovations. Establishments in the 'other' food products industry tend to lead when it comes to innovation, whereas fish product plants tend to lag.

Keywords: innovation, food processing, engineering practices, research and development. 



\section{Acknowledgements}

We wish to thank Valérie Gaudreault of the Micro-Economic Analysis Division at Statistics Canada for research assistance. 



\section{Introduction}

Innovation is the key to a firm's economic growth. Recent work that links dynamic panel datasets on the performance of firms and special surveys on the strategies that are being pursued by firms has demonstrated the importance of innovation to growth. Baldwin et al. (1994) demonstrate that in small and medium-sized Canadian firms, a measure of success that is based on growth, profitability and productivity is strongly related to the emphasis that firms place on innovation. Baldwin (1999) uses a sample of entrants to show that growth in new firms depends upon whether the firm innovates. Crepon, Duguet, and Mairesse (1998) find that innovation in French firms increases productivity.

While we have evidence, therefore, on the connection between success and innovation, there is less evidence on the factors that condition whether a firm adopts an innovation policy. Not all firms innovate despite the benefits of doing so. Research has, therefore, been aimed at understanding the conditions that are associated with being innovative. ${ }^{1}$ A number of questions have been posed in this literature--the effect of firm size and market structure on the intensity of innovation; whether the exclusive emphasis that is given to R\&D ignores the importance of other inputs and the extent to which multinational firms are more innovative. In this paper, we use data from the 1998 Survey of Advanced Technology in the Canadian Food Processing Industry to study the differences between firms that innovate and those that do not and to address the following set of issues.

The first is whether larger average firm size and less competition stimulate innovation. Often described as the Schumpeterian hypothesis, it is sometimes claimed that innovation is fostered by a climate where firms are large or in industries where there is less competition. While there is mixed evidence on both issues (Scherer, 1992), they continue to receive attention (Cohen and Klepper, 1996a, 1996b).

The second is whether an R\&D unit is essential to innovation. There is no doubt that firms use their R\&D units to create new products and processes, as well as to keep them informed about new developments made by other firms. However, it is not the only route that can be used to innovate. While it is traditional to emphasize the importance of $\mathrm{R} \& \mathrm{D}$ facilities to the innovation process, Mowery and Rosenberg (1989) have stressed that a good deal of innovation comes out of engineering departments and production facilities that are not normally considered to be part of the R\&D process.

The third relates to the importance of business practices on innovation. Innovation may require the adoption of certain advanced engineering and production practices, particularly practices that facilitate the development of new products and processes. Practices, such as rapid prototyping and computer-aided design, are used by the production and engineering departments of plants to

\footnotetext{
${ }^{1}$ For related studies covering France, Germany, Italy, Holland, and Switzerland, see Crepon, Duguet, and Kabla (1996), Felder et al. (1995), Sterlacchini (1994), Brouwer and Kleinknecht (1996), Arvanitis and Hollenstein (1994, 1996).
}

Analytical Studies Branch - Research Paper Series

$-1-$

Statistics Canada No. 11F0019MPE No. 101 
craft and assemble new products and develop new processes. Like R\&D, they can be considered as inputs to the innovation process. Some firms rely on an R\&D-based approach to innovation, whereas others rely more on a production-based approach. Still others use both. Here we investigate whether the use of business practices is as important an input into the innovation process as is $\mathrm{R} \& \mathrm{D}$.

Finally, we examine the effect of the nationality of a firm on its innovative tendencies. Both Dunning (1993) and Caves (1982) have stressed the special role of the multinational firm in transferring special innovation skills from one nation state to another. The role of multinationals in Canada is particularly important since they control over half of the manufacturing sector. McFetridge (1993) stresses the importance of linkages from Canada into the world innovation system that are accomplished through multinationals.

Throughout the exercise, we examine these issues for different types of innovations. Innovation surveys allow us to examine the determinants of the output of the innovative process. However, innovations vary considerably. Simply categorizing firms as innovative or non-innovative risks aggregating different types of innovators in a way that may hide important relationships. Therefore, we investigate the extent to which the determinants of innovation differ across innovation types, in particular, between product as opposed to process innovations.

The paper is organized as follows. First, the data sources are described. Second, the extent to which there are differences in innovation rates by plant size are examined. Then a description of the empirical model investigating the determinants of innovation in the food processing sector is given. This is followed by estimates of the model. Finally, a conclusion is provided.

\section{The Survey}

Earlier work has focused on manufacturing as a whole (Baldwin, Hanel, and Sabourin, 1999). Here we narrow our focus to a single industry within manufacturing-the food processing industry. This allows us to ask whether some of the same factors that are at work across all manufacturing industries also apply within a particular sector, thereby confirming that these factors are capturing general influences rather than industry-specific effects. For example, R\&D may be highly industry specific and multivariate studies that find a connection between innovation and $R \& D$ may just be capturing an industry-specific effect that is highly correlated with $R \& D$ intensity. By examining just food processing, we can investigate whether the intraindustry effects of R\&D are important. Despite the attempts of our earlier research to capture industry effects, these attempts may have been imperfect. By looking at firms within a particular sector like food processing, we can test whether intra-sectoral or intra-industry differences in firm activities like R\&D or concurrent engineering practices are driving innovative activity. 
The data for this study come from the 1998 Survey of Advanced Technology in the Canadian Food Processing Industry conducted by Statistics Canada. It is based on a frame of Canadian food processing establishments obtained from Statistics Canada's Business Register. ${ }^{2}$ Establishments were randomly sampled using strata that are based on establishment size, industry ${ }^{3}$ and country of control. The overall response rate to the survey was $84 \%$.

The questionnaire for the survey consists of nine sections covering a range of issues pertaining to the technological regime of food processing plants. ${ }^{4}$ There is an initial section dealing with general firm characteristics. This is followed by a section dealing with the production environment, then by two sections on advanced technology adoption and the use of associated business practices. Other sections investigate the development process for new technologies, skill development, the competitive environment firms face, the benefits obtained from technology adoption, the problems encountered during adoption, and the importance of government programs.

\section{Innovative Activities}

Innovations are categorized in the food processing survey as being one of two types-product or process. A product innovation is the commercial adoption of a brand new product or an existing product of higher quality. A process innovation is the use of new or improved production methods that lead to a reduction in unit production costs. Often product and process innovations occur simultaneously since the production of a new product may require a new or improved production method. These are referred to as combined product-process innovations.

Seventy-two percent of establishments in the food processing industry introduced at least one of these types of innovation during the three-year period 1995-1997. With regards to specific types of innovation, half of all plants introduced at least one product-only innovation; a third at least one process-only innovation; while slightly more than half introduced at least one combined product-process innovation.

In order to investigate plant-size differences, establishments were assigned to one of five size categories -10 to 19,520 to 49,50 to 99,100 to 249 , and 250 or more employees. The percentage of establishments in each of these size groups that introduced at least one of any type or of a specific type of innovation is provided in Table 1. As can be seen from the table, the innovation rate increases monotonically with plant size. Overall, the largest establishments are one-and-a-half times more likely to innovate than the smallest ones. Plant size differentials also exist across the specific types of innovation. These differences are most pronounced for processonly innovations, where large firms are three times more likely than small firms to introduce this type of innovation.

\footnotetext{
2 The Business Register maintains a listing of all establishments in the Canadian manufacturing sector. The food processing industry is major SIC (Standard Industrial Classification) group 10.

${ }^{3}$ The 3-digit SIC groupings within SIC 10 (food processing) were used for the sampling exercise.

${ }^{4}$ See Baldwin, Sabourin and West (1999).

${ }^{5}$ Establishments having fewer than 10 employees were not surveyed due to cost restraints.
} 
Table 1. Innovators by Employment Size (Establishment Weighted) ${ }^{6}$

\begin{tabular}{|l||c|c|c||c|}
\hline \multicolumn{1}{|c||}{$\begin{array}{c}\text { Size } \\
\text { (Number of Employees) }\end{array}$} & \multicolumn{4}{c|}{ INNOVATOR } \\
& Process Only & Product Only & $\begin{array}{c}\text { Product and } \\
\text { Process }\end{array}$ & Any Type \\
\hline $10-19$ & & & 39 & 57 \\
$20-49$ & 21 & 38 & 50 & 74 \\
$50-99$ & 30 & 52 & 53 & 76 \\
$100-249$ & 41 & 52 & 62 & 78 \\
250 or more & 45 & 56 & 74 & 84 \\
All & 60 & 60 & 53 & 72 \\
\hline
\end{tabular}

\section{Empirical Model}

\section{The Model}

Firms innovate in the expectation of receiving an increase in profits due to innovation. The expected post-innovation return to innovation activity $r_{i}^{*}$ for firm $i$ is taken to be a function of a set of firm-specific variables that determine how the firm responds to profitability incentives and industry-specific exogenous variables that condition the profitability of innovative activities. This may be formally expressed as:

$$
r_{i}^{*}=b x_{i}+u_{i}
$$

Even though $r_{i}^{*}$ is not directly observable, we can observe whether firm i innovated or not. We assume that when the expected return from innovation is positive, firms innovate. The observable binary variable $I_{i}$ takes a value of one when the firm is an innovator and zero otherwise. Thus we can write

$$
\begin{array}{ll}
I_{i}=1 & \text { if } r_{i} *>0 \\
I_{i}=0 & \text { otherwise }
\end{array}
$$

The expected return from innovation, given the characteristics of the firm and the industry to which it belongs, is

$$
E\left(r_{i}^{*} \mid x_{i}\right)
$$

Thus the probability of observing that a firm is innovative is given by

$$
\operatorname{Prob}\left(\mathrm{I}_{\mathrm{i}}=1\right)=\operatorname{Prob}\left(\mathrm{u}_{\mathrm{i}}>-\mathrm{bx} \mathrm{x}_{\mathrm{i}}\right)=1-\mathrm{F}\left(-\mathrm{bx}_{\mathrm{i}}\right)
$$

where $\mathrm{F}$ is the cumulative density function for the residuals $\mathrm{u}_{\mathrm{i}}$.

\footnotetext{
${ }^{6}$ Results are establishment weighted. Establishment weights refer to the probability sampling weights from the survey. Use of these weights provides population estimates rather than just sample estimates.
}

Analytical Studies Branch - Research Paper Series $\quad$ - 4 - $\quad$ Statistics Canada No. 11F0019MPE No. 101 
The choice of the statistical model depends on assumptions about the form of the residuals $u_{i}$. If the cumulative distribution of residuals is normal, the probit model is the appropriate choice; if it conforms to a logistic function, the logit model is appropriate. For practical purposes, the difference between the results of the two models is usually small. The logistic model will be used for our analysis.

Differences in expected profits from innovation and, therefore, differences in profitability are hypothesized to be related to differences in such characteristics as firm size, market structure, nationality of ownership, R\&D activity and engineering practices employed.

\section{Dependent Variable}

The dependent variable measures the innovative activity of a firm. Innovation is defined in two different ways in this paper. First, the incidence of innovation is captured by a dichotomous variable that measures whether or not firms have introduced an innovation of any type within the past three years. The binary variable takes a value of one for innovative firms, and zero for noninnovative firms.

Second, a set of three binary variables is used to distinguish between types of innovation. Three types of innovation are considered-product-only, process-only, and combined product-process innovation. The first variable takes a value of one if a firm has produced at least one product-only innovation and zero if it has produced no innovation. The second binary variable contrasts process-only innovators against non-innovators, while the third contrasts combined product/process innovators against non-innovators.

\section{Explanatory Variables}

Differences in innovative capabilities are considered to be partly related to differences in industry environment and partly related to differences in individual firm and plant characteristics that condition the underlying profitability of innovating. Therefore, innovation is postulated here to be a function of firm-specific, plant-specific and industry-specific characteristics. Since the survey was answered by plant managers, most responses pertain to the plant's operations. Plantspecific variables include plant size, engineering practices and number of competitors, while firm-specific variables include ownership and R\&D. But some responses were also obtained on the operations of the firm. Sector of activity is the sole industry-based variable. 


\section{Plant Characteristics and Activities}

\section{Size}

There are a number of reasons that large firms may find innovation to be more profitable than small firms. Large firms, it is often argued, have easier access to financing, can spread the fixed costs of innovation over a larger volume of sales and may benefit from economies of scope and complementarities between R\&D and other manufacturing activities (Cohen, 1996). Others contend that, as firms grow large, their $\mathrm{R} \& \mathrm{D}$ becomes less efficient. The empirical evidence is inconclusive (Scherer, 1992).

Size is measured here by the total number of employees in an establishment, including both production and non-production workers. Establishments are classified as belonging to one of five size categories-10 to 19,20 to 49,50 to 99,100 to 249 , and 250 or more employees. Five binary variables capture these size effects.

\section{Engineering and Development Practices}

Establishments employ a variety of engineering practices and techniques aimed at developing and improving products and processes. This study examines a set of practices designed to enhance product and process development. These practices are aimed at increasing the speed, efficiency and effectiveness of product and process development. Some are technology-based, such as computer-aided design, while others are procedure-oriented, such as rapid prototyping and continuous improvement. Gordon and Wiseman (1995) report that the adoption of practices, particularly those devoted to process development, provide more successful plants with a comparative advantage. Like $\mathrm{R} \& \mathrm{D}$, the use of advanced engineering activities is postulated to be an important input into the innovation process. Firms use their R\&D units to create new products and processes, as well as to keep them informed about new developments made by other firms. Their production and engineering units similarly use certain techniques and practices designed to facilitate innovation. It is the latter set with which we are concerned here.

There were nine practices pertaining to a plant's operations that were included in the questionnaire--rapid prototyping, quality function deployment, cross-functional design teams, concurrent engineering, computer-aided design, continuous improvement, process benchmarking, process simulation, and process value-added analysis. A binary variable has been constructed to capture their effect. It takes a value of one if a firm uses any one of the nine practices listed above, and a value of zero otherwise. 


\section{Competitive Conditions}

Firms active in less competitive markets have been hypothesized to be more innovative. Monopoly power, it is claimed, makes it easier for firms to appropriate the returns from innovation and provides the incentive to invest in innovation. However, this view is far from universal. Others, such as Arrow (1962), have argued that the gains from innovation at the margin are larger in an industry that is competitive than under monopoly conditions. Moreover, insulation from competitive pressure can breed bureaucratic inefficiency (Scherer, 1980). The earlier empirical evidence on the relationship between concentration and innovation is mixed (Cohen, 1996).

Number of competitors is used here to measure the degree of competition that a firm faces. Plants are grouped according to whether their manager indicated that they faced five or fewer competitors, ${ }^{7}$ six to 20 competitors, or more than 20 competitors and three binary variables are used to capture these competitive categories.

\section{Firm Characteristics and Activities}

\section{Nationality of Ownership}

Canada, because of its size and proximity to the United States, has a mixture of both Canadianowned and foreign-owned firms. Existing studies, relying on R\&D intensity, are inconclusive as to whether or not the nationality of ownership of a firm has an impact on its innovative activity. Caves et al. (1980, p. 193) suggest that foreign activity reduces the rate of R\&D activity in Canada. However, lower R\&D intensity may not signify less innovation if multinational subsidiaries import innovations from their parents. Using a survey for a limited number of firms in five industries, De Melto et al. (1980) reported that foreign firms operating in Canada were less R\&D intensive than their domestic counterparts, but that they accounted for a disproportionately large percentage of process innovations.

In order to investigate whether foreign-controlled firms are more likely to be innovative, a binary variable - taking a value of one if the plant is foreign-owned, and zero otherwise-is included.

\section{Research and Development}

Although neither a necessary nor a sufficient condition for innovation (Äkerblom et al., 1996; Baldwin, 1997), R\&D is an important input into the innovation process. Firms with an effective R\&D program are not only more likely to create new products and processes but are also more receptive to the technological advances of others (Mowery and Rosenberg, 1989). A binary variable was constructed to capture this effect, taking a value of one if the parent of the plant surveyed performs $R \& D$, zero otherwise.

\footnotetext{
${ }^{7}$ This is the number of competitors that the plant manager felt offered competing products to his/her own. 


\section{Industry Effects}

\section{Industry}

Industry effects were also included since technological opportunities and profitability of innovation often vary across industries. Seven sub-industries are considered-bakery, cereal, dairy, fish, fruit and vegetables, meat, and other food products. In order to capture industry effects, seven binary variables were constructed, one for each of the industries. Each variable takes a value of one if the establishment belongs to that particular industry, zero otherwise.

The variables that are used in the regression analysis are listed in Table 2, along with a short description of the variable, and its mean and standard deviation.

\section{Estimation Procedures}

Our model consists of the following equation:

$$
\begin{gathered}
\text { INNOV }=\alpha_{0}+\alpha_{1} * \text { SIZE }+\alpha_{2} * \text { FOREIGN }+\alpha_{3} * \text { R } \& D+\alpha_{4} * \text { ENG_PRACT } \\
+\alpha_{5} * \text { INDUSTRY }+\alpha_{6} * \text { COMPET }
\end{gathered}
$$

INNOV is a binary dependent variable indicating whether or not a firm is innovative. SIZE is the plant employment size, while FOREIGN measures whether a firm is controlled from abroad. R\&D measures whether a firm performs research and development. ENG_PRACT refers to a set of product and process development techniques used by the establishment. INDUSTRY is a set of seven binary variables used to indicate the 3-digit industry in which the establishment is found. COMPET captures the number of competitors a plant faces. 
Table 2. Overview of Dependent and Independent Variables

\begin{tabular}{|c|c|c|c|}
\hline Variable & Description & Mean & $\begin{array}{l}\text { Standard } \\
\text { Deviation }\end{array}$ \\
\hline $\begin{array}{l}\text { 1. Dependent Variables } \\
\text { Innovation } \\
\text { INNOVATE } \\
\text { PRODINOV } \\
\text { PROCINOV } \\
\text { BOTHINOV } \\
\end{array}$ & $\begin{array}{l}\text { Innovator/non-innovator } \\
\text { - any type of innovation } \\
\text { - product-only innovation } \\
\text { - process-only innovation } \\
\text { - combined product-process innovation }\end{array}$ & $\begin{array}{l}0.72 \\
0.50 \\
0.36 \\
0.53\end{array}$ & $\begin{array}{l}0.45 \\
0.50 \\
0.48 \\
0.50\end{array}$ \\
\hline $\begin{array}{l}\text { 2. Independent Variables } \\
\text { Plant Characteristics and Activities }\end{array}$ & & & \\
\hline $\begin{array}{l}\text { Size } \\
\text { ESTSIZE1 } \\
\text { ESTSIZE2 } \\
\text { ESTSIZE3 } \\
\text { ESTSIZE4 } \\
\text { ESTSIZE5 }\end{array}$ & $\begin{array}{l}\text { Employment Size } \\
\text { - } 10 \text { to } 19 \text { employees } \\
\text { - } 20 \text { to } 49 \text { employees } \\
\text { - } 50 \text { to } 99 \text { employees } \\
\text { - } 100 \text { to } 249 \text { employees } \\
\text { - } 250 \text { or more employees }\end{array}$ & $\begin{array}{l}0.23 \\
0.29 \\
0.20 \\
0.18 \\
0.11\end{array}$ & $\begin{array}{l}0.42 \\
0.45 \\
0.40 \\
0.39 \\
0.31\end{array}$ \\
\hline $\begin{array}{l}\text { Engineering Practices } \\
\text { ENG_PRACT } \\
\text { Competition }\end{array}$ & $\begin{array}{l}\text { Engineering Practices } \\
\text { - Product/process development practices } \\
\text { Number of Competitors }\end{array}$ & 0.66 & 0.47 \\
\hline $\begin{array}{l}\text { COMPET1 } \\
\text { COMPET2 } \\
\text { COMPET3 }\end{array}$ & $\begin{array}{l}\text { - Five or fewer competitors } \\
\text { - Six to } 20 \text { competitors } \\
\text { - More than } 20 \text { competitors }\end{array}$ & $\begin{array}{l}0.27 \\
0.36 \\
0.37\end{array}$ & $\begin{array}{l}0.45 \\
0.48 \\
0.48\end{array}$ \\
\hline Firm Characteristics and Activities & & & \\
\hline $\begin{array}{l}\text { Ownership } \\
\text { FOREIGN } \\
\text { R\&D Activity }\end{array}$ & $\begin{array}{l}\text { Nationality of Ownership } \\
\text { - Foreign owned } \\
\text { R\&D Activity }\end{array}$ & 0.11 & 0.32 \\
\hline $\begin{array}{l}\text { RADDOER } \\
\text { Industry Characteristics } \\
\text { Industry }\end{array}$ & - R\&D performer & 0.59 & 0.49 \\
\hline $\begin{array}{l}\text { IND_BAKE } \\
\text { IND_CERE } \\
\text { IND_DAIR } \\
\text { IND_FISH } \\
\text { IND_VEGG } \\
\text { IND_MEAT } \\
\text { IND_OTHR } \\
\end{array}$ & $\begin{array}{l}\text { Bakery industry } \\
\text { Cereal industry } \\
\text { Dairy industry } \\
\text { Fish products industry } \\
\text { Fruit and vegetables industry } \\
\text { Meat industry } \\
\text { 'Other' food products industry }\end{array}$ & $\begin{array}{l}0.15 \\
0.15 \\
0.10 \\
0.15 \\
0.08 \\
0.19 \\
0.19\end{array}$ & $\begin{array}{l}0.36 \\
0.35 \\
0.30 \\
0.36 \\
0.27 \\
0.39 \\
0.39\end{array}$ \\
\hline
\end{tabular}




\section{Empirical Results}

\section{Incidence of Innovation}

The results of the logistic regression models for the probability of a firm being innovative are given in Table 3. Two weighted ${ }^{8}$ logistic estimates are provided. In the first model (column 1), the likelihood of introducing any type of innovation is estimated using establishment size, nationality of ownership, R\&D activity, industry and number of competitors as the explanatory variables. In the second (column 2), engineering practices have been added to the basic model. All regressions are estimated against an excluded firm that is small, Canadian-owned, does not perform R\&D, does not use advanced product and process development engineering practices, is in the bakery industry, and faces few competitors.

The parameter results in Table 3 provide the qualitative effects of the explanatory variables. In order to present quantitative effects, we provide probability estimates in Table 4 that correspond to the specification that includes engineering practices. The probabilities are calculated by estimating the logit function at the sample means. ${ }^{9}$

The coefficient on R\&D is positive and highly significant. Firms performing R\&D are much more likely to introduce an innovation. This accords with other studies (Cohen and Klepper, 1996a; Baldwin, 1997; Baldwin, Hanel, and Sabourin, 1999). A non-R\&D performer has only about a fifty percent chance of innovating (Table 4). By contrast, an R\&D performer has over an eighty percent chance of being an innovator. $R \& D$ is neither a necessary nor a sufficient condition for being an innovator. But performing $R \& D$ increases the probability of success by around sixty percent.

$R \& D$ is not the only input that is significantly related to the innovation process. The coefficient on engineering practices in Table 3 is positive and highly significant. Establishments that adopt these practices are significantly more likely to be innovative. Equally noteworthy is the size of the effect of the adoption of these engineering practices provided in Table 4, especially in comparison to the effect of performing R\&D. When advanced engineering practices are implemented, the probability of successful innovation moves from sixty to eighty percent-an increase of one-third. Moreover, using these practices, the probability of being an innovator rivals that of an $R \& D$ performer.

Plant size is highly statistically significant in the first model, when the engineering practices are omitted. Large plants are more likely to innovate than are smaller plants. Once engineering practices are included, however, the story changes. Size effects are diminished. Being larger adds only about 10 percentage points to the probability of success, where the effect of size is significant. Thus, much of the size differential in innovation rates is attributable to differences in

\footnotetext{
${ }^{8}$ The weights that are used are the probability sampling weights from the survey.

${ }^{9}$ Probabilities (p) are estimated using the logit equation: $\mathrm{P}=\exp (\beta \mathrm{x}) /[1+\exp (\beta \mathrm{x})]$
} 
the product and process development techniques being used by firms of differing sizes. Once this activity is taken into account, there is less of an effect of size on innovation.

A similar story is found for nationality of ownership. The coefficient on nationality of ownership is positive and statistically significant if engineering practices are omitted. Once they are included, however, the ownership coefficient becomes smaller and loses its significance. Foreign-owned firms are more likely to adopt these types of practices and once these factors have been accounted for, the effect of nationality on innovation is reduced. Much of the size and ownership effects reflect differences in the use of these engineering practices.

Competition is weakly significant. Plants facing moderate and heavy competition are more likely to innovate than those facing few competitors. However, the effect on the probability of success is relatively small - only one to six percentage points. Moreover, the marginal effects are larger as markets move from oligopolistic (less than 5 competitors) to more competitive (6 to 20 competitors) than they are for movement to the last stage of more atomistic competition (more than 20 competitors).

The industry to which an establishment belongs influences the likelihood that it will innovate. Establishments in the bakery and 'other' food products industries are found to be the most likely to be innovative, while establishments in the fish products industry are the least likely. The difference between fish and the bakery or 'other' sectors is about 20 percentage points-an increase of about one-third in the probability of innovating.

\section{Incidence by Type of Innovation}

The parameter and probability estimates for the three specific forms of innovation are also provided in Tables 3 and 4-product-only, process-only, and combined product-process innovations.

Many of the factors important for process innovation are also found to be important for product innovation. But some differences do exist. Size is both more significant and more important for process innovation than for both product innovation and combined product-process innovation (Table 4). For process innovation, the larger the establishment, the greater the likelihood of being innovative. The probability of a plant introducing a process-only innovation increases monotonically with the size of the plants-ranging from $18 \%$ for the smallest size group (10-19 employees), to $36 \%$ for medium-sized plants (50 to 99 employees), to $49 \%$ for the largest plants (250 or more employees). This is consistent with the findings of Cohen and Klepper (1996a, 1996b) that plant size is more closely related to process than product innovation. As for productonly innovations, it is the medium-sized plants that have the highest probabilities of adopting $(55 \%)$, while for combined product-process innovations, it is the largest plants that are the most likely $(66 \%)$ to introduce these more complex types of innovation. 
$\mathrm{R} \& \mathrm{D}$ is also important across all types of innovations, but it is largest for product-only innovations. For product-only innovation, there is a $59 \%$ probability that an R\&D performer will introduce a product-only innovation compared to only a $35 \%$ probability for non-R\&D doers. This is a difference of 24 percentage points. However, the probability that a firm, which conducts $\mathrm{R} \& \mathrm{D}$, will introduce a process-only innovation is $37 \%$, compared to only $22 \%$ for those that do not-a difference of 15 percentage points. While the probability that an R\&D performer will introduce a new product is higher than the probability that they will introduce a new process in the food processing industry, the relative percentage increase in the probability of innovation associated with R\&D is quite similar in both cases. In this narrower sense, R\&D performance may be said to have about an equal impact in these two areas.

Product and process development practices are highly significant across all types of innovations. Firms that use the latest techniques with regards to product and process development are more likely to introduce innovations of all types. For example, plants employing these practices have a probability of $36 \%$ of introducing a process-only innovation, and $54 \%$ of introducing a productonly innovation. Plants not using these practices have only a probability of $20 \%$ and $38 \%$ of introducing a process-only, and product-only innovation, respectively. This is a difference of 16 percentage points in both cases, though the relative increase is greater for process innovations.

Nationality of ownership is positive across all types of innovation but is significant only for process-only innovations. For process-only innovations, the effect is large. Forty-two percent of foreign-owned plants introduce process-only innovations, compared to only $29 \%$ of domesticowned plants. Foreign-ownership increases the probability of process innovation by about 50 percent. This is consistent with the findings of De Melto et al. (1980) that foreign firms operating in Canada account for a disproportionately large percentage of process innovations. It also supports the claim that multinational firms are important conduits for transferring technological knowledge in the form of process innovations (Caves, 1982).

Competition stimulates both product and process innovations, but the pattern is different. Establishments facing moderate competition are much more likely to introduce a product innovation and are slightly more likely to introduce a combined product-process innovation than those facing few competitors, or those facing the most intense competition. For example, the probability of introducing a product-only innovation is $58 \%$ for those with moderate competition, $48 \%$ for high competition, and $38 \%$ for little competition. However, for process innovation, the probability of innovation is highest in the group with the largest number of competitors. The probability that a plant, in a highly competitive market, will introduce a process-only innovation is $38 \%$ compared to only $26 \%$ for those facing fewer competitors.

Industry effects are most pronounced for process-only and product-only innovations. Few significant industry differences are found for combined product-process innovations. 
Table 3. Logistic Model of Determinants of Innovation Activity (Establishment Weighted)

\begin{tabular}{|c|c|c|c|c|c|}
\hline \multirow[b]{2}{*}{ VARIABLES } & \multicolumn{2}{|c|}{ ANY INNOVATION } & \multicolumn{3}{|c|}{ SPECIFIC TYPE OF INNOVATION } \\
\hline & Specification 1 & Specification 2 & Process Only & Product Only & Product-Process \\
\hline $\begin{array}{l}\text { Log Likelihood } \\
\text { Intercept }\end{array}$ & $\begin{array}{l}-411 \\
-0.408 \\
\end{array}$ & $\begin{array}{l}-398 \\
-0.743 * * \\
\end{array}$ & $\begin{array}{l}-471 \\
-3.514 * * * \\
\end{array}$ & $\begin{array}{l}-506 \\
-1.328 * * * \\
\end{array}$ & $\begin{array}{l}-518 \\
-1.273 * * * \\
\end{array}$ \\
\hline $\begin{array}{l}\text { PLANT CHARACTERISTICS } \\
\text { Plant Size } \\
\text { - } 20 \text { to } 49 \text { employees } \\
\text { - } \quad 50 \text { to } 99 \text { employees } \\
\text { - } 100 \text { to } 249 \text { employees } \\
\text { - } \quad 250 \text { or more employees } \\
\text { Engineering Practices } \\
\text { - } \quad \text { product/process development } \\
\text { Competition } \\
\text { - } 6 \text { to } 20 \text { competitors } \\
\text { - } \quad \text { more than } 20 \text { competitors } \\
\end{array}$ & $\begin{array}{l}0.625^{* * *} \\
0.622^{* *} \\
0.731^{* * *} \\
0.892^{* *} \\
\\
--- \\
0.368 \\
0.435^{*} \\
\end{array}$ & $\begin{array}{l}0.516^{* *} \\
0.487 \\
0.551^{*} \\
0.583 \\
0.962 * * * \\
0.393 * \\
0.473 * \\
\end{array}$ & $\begin{array}{l}0.457 * \\
0.956^{* * *} \\
1.143^{* * *} \\
1.458^{* * *} \\
\\
0.831^{* * *} \\
0.292 \\
0.578^{* *} \\
\end{array}$ & $\begin{array}{l}0.411^{*} \\
0.269 \\
0.471^{*} \\
0.440 \\
\\
0.668^{* * * *} \\
0.834 * * * \\
0.435^{* *} \\
\end{array}$ & $\begin{array}{l}0.134 \\
0.109 \\
0.467 * \\
0.829 * * * \\
\\
0.829 * * * \\
0.386^{*} \\
0.119 \\
\end{array}$ \\
\hline $\begin{array}{l}\text { FIRM CHARACTERISTICS } \\
\text { Ownership } \\
\text { - foreign } \\
\text { R\&D Activity } \\
\text { - R\&D doer } \\
\end{array}$ & $\begin{array}{l}0.677 * * \\
1.827 * * * \\
\end{array}$ & $\begin{array}{l}0.396 \\
1.649 * * * \\
\end{array}$ & $\begin{array}{l}0.599 * * \\
0.717 * * * \\
\end{array}$ & $\begin{array}{l}0.308 \\
1.011^{* * *}\end{array}$ & $\begin{array}{l}0.272 \\
0.849 * * *\end{array}$ \\
\hline $\begin{array}{l}\text { INDUSTRY CHARACTERISTICS } \\
\text { Industry } \\
\text { Cereal } \\
\text { Dairy } \\
\text { Fish } \\
\text { Fruit and vegetables } \\
\text { Meat } \\
\text { Other } \\
\text { N }\end{array}$ & $\begin{array}{l}-0.625^{*} \\
-0.277 \\
-0.801 * * \\
-0.303 \\
-0.609 * * \\
0.115 \\
842\end{array}$ & $\begin{array}{l}-0.656^{*} \\
-0.288 \\
-0.843^{* * *} \\
-0.411 \\
-0.625^{*} \\
0.064 \\
842\end{array}$ & $\begin{array}{l}1.150 * * * \\
0.745 * * * \\
0.074 \\
0.882^{* * * *} \\
1.030^{* * * *} \\
1.291 * * * \\
842\end{array}$ & $\begin{array}{l}-0.701 * * \\
-0.256 \\
-1.379 * * * \\
-0.469 \\
-0.597 * * \\
-0.074 \\
841\end{array}$ & $\begin{array}{l}-0.518^{*} \\
-0.012 \\
-0.184 \\
-0.252 \\
-0.174 \\
0.289 \\
842\end{array}$ \\
\hline
\end{tabular}

Note: *** significant at the $1 \%$ level; ** significant at the $5 \%$ level; $*$ significant at the $10 \%$ level. 
Table 4. Estimated Probability of Introducing an Innovation

\begin{tabular}{|c|c|c|c|c|}
\hline & $\begin{array}{c}\text { Any } \\
\text { Innovation }\end{array}$ & Process Only & Product Only & $\begin{array}{l}\text { Product and } \\
\text { Process }\end{array}$ \\
\hline & & (per & & \\
\hline PLANT CHARACTERISTICS & & & & \\
\hline Establishment Size & & & & \\
\hline 10 to 19 employees & 70 & 18 & 44 & 46 \\
\hline 20 to 49 employees & 80 & 26 & 54 & 46 \\
\hline 50 to 99 employees & 70 & 36 & 44 & 46 \\
\hline 100 to 249 employees & 80 & 41 & 56 & 58 \\
\hline 250 or more employees & 70 & 49 & 44 & 66 \\
\hline Engineering Practices & & & & \\
\hline Engineering Practice User & 80 & 36 & 54 & 57 \\
\hline Non User & 61 & 20 & 38 & 37 \\
\hline Number of Competitors & & & & \\
\hline 0 to 5 & 68 & 26 & 38 & 47 \\
\hline 6 to 20 & 76 & 26 & 58 & 56 \\
\hline more than 20 & 78 & 38 & 48 & 47 \\
\hline FIRM CHARACTERISTICS & & & & \\
\hline Nationality of Ownership & & & & \\
\hline Foreign & 75 & 42 & 49 & 50 \\
\hline Canadian & 75 & 29 & 49 & 50 \\
\hline R\&D Activity & & & & \\
\hline R\&D performer & 85 & 37 & 59 & 59 \\
\hline Non-performer & 53 & 22 & 35 & 38 \\
\hline INDUSTRY CHARACTERIST & & & & \\
\hline Industry & & & & \\
\hline Bakery & 81 & 17 & 59 & 52 \\
\hline Cereal & 68 & 39 & 42 & 39 \\
\hline Dairy & 81 & 30 & 59 & 52 \\
\hline Fish & 64 & 17 & 27 & 52 \\
\hline Fruit and vegetables & 81 & 33 & 59 & 52 \\
\hline Meat & 69 & 37 & 44 & 52 \\
\hline Other & 81 & 43 & 59 & 52 \\
\hline
\end{tabular}




\section{Conclusion}

Research and development is often seen as an important building block for innovation. But just how important it is often remains an unanswered question. As Mowery and Rosenberg (1989) point out, R\&D is not necessary for the development of new products and processes. And of course, luck and competence determine whether an invention that is discovered by an $R \& D$ group will eventually turn into a commercial success.

Research is, therefore, neither a necessary nor a sufficient condition behind successful innovation. The results of our analysis place quantitative bounds around this issue. On the one hand, they provide estimates of the probability that innovation will occur even if no R\&D is done. On the other hand, they provide estimates of the probability of an innovation being introduced if $R \& D$ is performed. In the food processing sector, there is a 53\% probability of innovating without an R\&D unit. This increases to over $80 \%$ in those plants benefiting from an R\&D unit. Although R\&D does not guarantee success, the probability of introducing an innovation is one-and-a-half times greater for $R \& D$ performers than for those without an $R \& D$ unit.

Much attention has been focused at the importance of R\&D to the innovation process. This attention has been directed both at understanding the process and providing empirical measures of its importance. But there are clearly other inputs to the innovation process, many of which occur in production and engineering departments. The innovation process is not completely linear, running from R\&D to commercial development. The design and engineering department may contribute through improvements to the assembly process of new products, thereby making substantial contributions to process innovations. Even in linear innovation systems, where the process of innovation is begun in $\mathrm{R} \& \mathrm{D}$ labs, companies must develop complementary production competencies if they are to bring new products successfully to market. Practices like concurrent engineering reduce development costs and, therefore, the price at which the product can be sold. Practices related to quality control ensure that the product has sufficient customer appeal that it can be successfully marketed.

It has not proven easy to develop measures of R\&D. A substantial international effort has coordinated attempts to do so over the last thirty years. It is even more difficult to measure the complementary or substitute skills in engineering and production departments. In this paper, we make use of new questions that explore whether firms have implemented certain of these practices. Our results confirm the need to move beyond the conventional R\&D-centric approach. The use of these engineering practices is found to be very important. Engineering practices are highly significant for all types of innovation, particularly for those involving process innovations. Engineering practices are an important part of the technological regime of a firm. They serve as complements to advanced technologies. Implementing these practices is associated with about an $80 \%$ probability of innovation-just as high as for the implementation of an R\&D program. Moreover, there is a considerable difference between the probability of innovating for those who develop these advanced production competencies and those who do not. Our results show that the effect of engineering practices on innovation is as important as R\&D for process-only innovations, and only slightly behind when it comes to product-only innovations. This supports 
the contention of Mowery and Rosenberg (1989) that the production and engineering departments are key players in the innovation process.

We have also focused on the oft-repeated contention that increasing firm size and decreasing market competition would lead to more innovation. We do not find support for the lack of competition hypothesis. Indeed, we find evidence that increasing competition is associated with more innovation. In fact, intermediate and higher levels of competition are more conducive to innovation than the lowest level of competition.

On the other hand, size is positively related to the probability of innovating. But the magnitude and statistical significance of the size effect are reduced substantially when the production and engineering competencies of the plant are taken into consideration. This result has been found in other studies (Baldwin, Hanel, and Sabourin, 1999). Large firms differ from small firms in the extent to which they develop certain competencies. Once these are taken into account, the size effects are reduced.

Canada is a small, developed country with an open economy and a substantial amount of foreign investment. The effect of foreign investment on economic activity is, therefore, of considerable interest. We find that foreign controlled plants in the food processing sector are more likely to introduce an innovation. As with the size effect, the foreign-ownership effect is reduced when R\&D and engineering practices are taken into account. Differences in the product innovation rates that exist between foreign and domestic firms plants are accounted for, in large part, by differences in the engineering practices employed. This is not true for process-only innovations. Here, nationality of ownership is positive and highly significant even after engineering practices are taken into account. This supports the claim that an important function of multinational firms is the ability to transfer technological knowledge, in the form of process innovations, from the parent company to the Canadian subsidiary (Caves, 1982).

Finally, industry matters in that some industries are inherently more innovative than others. Establishments in the 'other' food products industry lead for all types of innovation, whereas fish product plants lag for all but combined product-process innovations. Bakery plants exhibit mixed results. They tend to lead in product-only innovations and lag in process-only innovations. 


\section{References}

Äkerblom, M., M. Virtaharju and A. Leppäahti. 1996. "A Comparison of R\&D Surveys, Innovation Surveys and Parent Statistics Based on Finnish Data", Innovation, Patents and Technological Strategies. Paris: OECD.

Arrow, K. 1962. "Economic Welfare and the Allocation of Resources for Invention", in The Rate and Direction of Inventive Activity. Edited by R.R. Nelson. Princeton: Princeton University Press.

Arvanitis, S. and H. Hollenstein. 1994. "Demand and Supply Factors in Explaining the Innovative Activity of Swiss Manufacturing Firms", Economics of Innovation and New Technology. 3: 15-30.

Arvanitis, S. and H. Hollenstein. 1996. "Industrial Innovation in Switzerland: A Model-based Analysis with Survey Data", in Determinants of Innovation: The Message from New Indicators. Edited by Alfred Kleinknecht. Amsterdam: Macmillan. pp. 13-62.

Baldwin, J.R. 1997. The Importance of Research and Development for Innovation in Small and Large Canadian Manufacturing Firms. Research Paper Series No. 107. Ottawa: Statistics Canada.

Baldwin, J.R. 1999. "Innovation and Entry", in Are Small Firms Important? Their Role and Impact. Edited by Z. Acs. Dordrecht: Kluwer. Forthcoming.

Baldwin, J.R., W. Chandler, Can Le and T. Papailiadis. 1994. Strategies for Success: A Profile of Growing Small and Medium-Sized Enterprises in Canada. Catalogue 61-523R. Ottawa: Statistics Canada.

Baldwin, J.R., P. Hanel and D. Sabourin. 1999. "Determinants of Innovative Activity in Canadian Manufacturing: The Role of Intellectual Property Rights". Forthcoming Research Paper.

Baldwin, J.R. and D. Sabourin. 1995. Technology Adoption in Canadian Manufacturing. Catalogue 88-512. Ottawa: Statistics Canada.

Baldwin, J.R., D. Sabourin and D. West. 1999. Advanced Technology in the Canadian Food Processing Industry. Catalogue 88-518. Ottawa: Statistics Canada. Forthcoming.

Brouwer, E. and A. Kleinknecht. 1996. "Determinants of Innovation. A Microeconometric Analysis of Three Alternative Innovation Output Indicators". In Determinants of Innovation: The Message from New Indicators. Edited by A. Kleinknecht. Amsterdam: Macmillan. pp. 99124. 
Caves, R.E., M.E. Porter, A.M. Spence with J.T. Scott. 1980. Competition in the Open Economy: A Model Applied to Canada. Cambridge: Mass: Harvard University Press.

Caves, R.E. 1982. Multinational Enterprise and Economic Analysis. Cambridge: Cambridge University Press.

Cohen, W. 1996. "Empirical Studies of Innovative Activity". In P. Stoneman (ed.) The Handbook of the Economics of Technological Change. Oxford: Basil Blackwell. pp. 182-264.

Cohen, W. and S. Klepper. 1996a. “A Reprise of Size and R\&D”, Economic Journal 106: 925952.

Cohen, W. and S. Klepper. 1996b. "Firm Size and the Nature of Innovation Within Industries: The Case of Process and Product R\&D”, Review of Economics and Statistics 78: 232-243.

Crepon, B., E. Duguet and I. Kabla. 1996. "Schumpeterian Conjectures: A Moderate Support from Various Innovation Measures", in Determinants of Innovation: The Message from New Indicators. Edited by A. Kleinknecht. Amsterdam: MacMillan. pp. 63-98.

Crepon, B., E. Duguet and J. Mairesse. 1998. "Research Investment, Innovation and Productivity: An Econometric Analysis at the Firm Level”, \#98.15. Cahiers Eco and Maths. University of Paris 1-Pantheon-Sorbonne.

De Melto, D., K. McMullen and R. Wills. 1980. Innovation and Technological Change in Five Canadian Industries. Discussion Paper No. 176. Ottawa: Economic Council of Canada.

Dunning, J.H. 1993. Multinational Enterprises and the Global Economy. Toronto: AddisonWesley.

Felder, J., G. Licht, E. Nerlinger and H. Stahl. 1995. "Factors Determining R\&D and Innovation Expenditure in German Manufacturing Industries" in Determinants of Innovation: The Message from New Indicators. Edited by A. Kleinknecht. Amsterdam: MacMillan. pp. 125-54.

Gordon, John and Joe Wiseman. 1995. "Thriving on Competition", in Business Quarterly. London, Ontario: The University of Western Ontario.

Leo, H. 1996. "Determinants of Product and Process Innovation”, Économies et Sociétés, Dynamique technologique et organisation, Série W, 3: 61-77.

McFetridge, D. 1993. The Canadian System of Innovation", in National Innovation Systems. Edited by R.R. Nelson. Oxford: Oxford University Press. pp. 299-323.

Mowery, D.C. and N. Rosenberg. 1989. Technology and the Pursuit of Economic Growth. Cambridge: Cambridge University Press. 
Scherer, F.M. 1980. Industrial Market Structure and Economic Performance, $2^{\text {nd }}$ edition, Chicago: Rand McNally College Publishing Company.

Scherer, F.M. 1992. "Schumpeter and Plausible Capitalism", Journal of Economic Literature 30: 1416-34.

Sterlacchini, A. 1994. "Technological Opportunities, Intraindustry Spillovers and Firm R\&D Intensity", Economic Innovation and New Technology 3: 123-37.

Suits, D.B. 1983. "Dummy Variables: Mechanics vs. Interpretation”. The Review of Economics and Statistics. 65: 177-181. 